\title{
Reverse Osmosis and Membrane Distillation for Desalination of Groundwater: A Review
}

\author{
Bhausaheb L. Pangarkar, ${ }^{1}$ Mukund G. Sane, ${ }^{2}$ and Mahendra Guddad ${ }^{1}$ \\ ${ }^{1}$ Sir Visvesvaraya Institute of Technology, University of Pune, Chincholi, Nashik 422 101, India \\ ${ }^{2}$ National Chemical Laboratory, Pune 411008, India \\ Correspondence should be addressed to Bhausaheb L. Pangarkar, pbl_1978@yahoo.com
}

Received 3 April 2011; Accepted 10 May 2011

Academic Editors: M. Giovannini and N. Munroe

Copyright (C) 2011 Bhausaheb L. Pangarkar et al. This is an open access article distributed under the Creative Commons Attribution License, which permits unrestricted use, distribution, and reproduction in any medium, provided the original work is properly cited.

\begin{abstract}
In recent years, the increasing threat to groundwater quality due to human activities has become a matter of great concern. The groundwater quality problems present today are caused by contamination and by overexploitation, or by combination of both, which are faced by many Indian states. Today, reverse osmosis (RO) membranes are the leading technology for desalination of groundwater because of their strong separation capabilities and exhibiting a great potential for treatment of waters worldwide. However, the RO process had some problems due to the formation of polarization films because high pressure operation and by-products which may generate bacteria and fouling. Also, high energy consumption and brine disposal problem is faced in RO process due to the limited recovery of water. These problems may be overcome by other membrane thermal process such as a membrane distillation (MD). This paper addresses the outline of RO and MD process for desalination. RO has developed over the past 40 years and MD is an emerging technology for brackish water desalination and yet is not fully implemented in industry. The $\mathrm{MD}$ is the better alternative to RO for desalination theoretically found in the literature.
\end{abstract}

\section{Introduction}

Water is the source of life, the basis of human survival, and the principal material base to guarantee the economy substantial development of a country. With increasing global population, the gap between the supply and demand for water is widening and is reaching such alarming levels that in some part of the world, it is posing a threat to human existence [1]. The fresh water scarcity is a growing problem all over the world because only $1 \%$ of earth's water is fresh water available for human to drink [2]. The US geological survey found that $96.5 \%$ of earth's water is located in seas and oceans and $1.7 \%$ of earth's water is located in the ice caps. The remaining percentage is made up of brackish water, slightly salty water found as surface water in estuaries and as groundwater in salty aquifers [3]. The need for fresh water is at the top of the international agenda of critical problems, at least as firmly as climate change. India as a country has $16 \%$ of the world's population and $4 \%$ of its fresh water resources [4].
Due to rapid industrialization and development, there is an increased opportunity for grey water reuse in developing countries such as India. Although India occupies only 3.29 million $\mathrm{km}^{2}$ geographical area, which forms $2.4 \%$ of the world's land area, it supports over $15 \%$ of world's population. The population of India as of March 31, 2011 was $1,210,193,422$ persons (Census, 2011). India also has a livestock population of 500 million, which is about $20 \%$ of world's total livestock. However total annual utilizable water resources of the country are $1086 \mathrm{~km}^{3}$ which is only $4 \%$ of world's water resources [5]. Total annual utilizable resources of surface water and groundwater are $690 \mathrm{~km}^{3}$ and $396 \mathrm{~km}^{3}$, respectively [6]. Consequent to rapid growth in population and increasing water demand, stress on water resources in India is increasing and per capita water availability is reducing day by day. In India, per capita surface water availability in the years 1991 and 2001 were $2300 \mathrm{~m}^{3}\left(6.3 \mathrm{~m}^{3} /\right.$ day $)$ and $1980 \mathrm{~m}^{3}\left(5.7 \mathrm{~m}^{3} /\right.$ day $)$, respectively, and these are projected to reduce to 1401 and $1191 \mathrm{~m}^{3}$ by the years 2025 and 2050, respectively [5]. Total water requirement of the country in 
2050 is estimated to be $1450 \mathrm{~km}^{3}$ which is higher than the current availability of $1086 \mathrm{~km}^{3}$.

Pure, clean water is an absolute must for our survival. Water resources used by humans for various domestic purposes such as drinking, cooking food, washing clothes, baths, recreations, flushing toilets, and car washing. Water is also used for various industrial purposes, agricultural purposes, power generation, fishing, and so forth. The quantity of available fresh water is inadequate to meet the growing demands of human beings. The conventional water sources, like rivers, lakes, ponds, and so forth, in the form of surface water are not fully dependable because most of these are rain fed. Presently, rainfall is below normal in most of the years. This results in failure of many surface water source schemes. Similarly, due to the reasons stated already the subsurface sources also fail in certain extent. Experts estimate that over 1 billion people are without clean drinking water. Each year more than 5 million people die from waterrelated diseases; 4 million of them are children. Increasing demands on water and an ever-increasing population mean that water supply is becoming a serious issue $[3,7]$.

Despite an estimated total of Rs 1105 billion spent on providing safe drinking water since the first Five-Year Plan was launched in 1951, lack of safe and secure drinking water continues to be a major hurdle and a national economic burden [4]. As a consequence of the growing scarcity of freshwater, the implementation of the desalination plants is increasing on a large scale. According to a report by Frost and Sullivan, with growing demand and more focus on desalination by the Indian states, the desalination capacity of India is expected to reach 1,449,942 $\mathrm{m}^{3}$ /day by 2015 from $291,820 \mathrm{~m}^{3}$ /day in 2008 [8].

The crucial role groundwater plays as a decentralized source of drinking water for millions of rural and urban families cannot be overstated. However, due to rapid growth of population, urbanization, industrialization, and agriculture activities, groundwater resources are under stress. There is growing concern on the deterioration of groundwater quality due to geogenic and an anthropogenic activity [9].

Groundwater is generally less susceptible to contamination and pollution when compared to surface water bodies. The desalination of the available saline water has become a suitable alternative, which is widely used worldwide [1012]. The well-established seawater and brackish groundwater desalination technologies, no doubt, can be employed to produce large amounts of good-quality water at a cost which appears to be reasonably quite competitive, but the main drawback of all such processes still remaining to be resolved is the high energy consumption [4].

Desalination of seawater or saline water has been practiced regularly for over 50 years and is well-established means of water supply in many countries. It is now feasible, technically and economically, to produce large quantities of water of excellent quantity from desalination processes. Challenges, however, still exist to produce desalination water for relatively large communities, for their continuous growth, development, and health, and for modern efficient agriculture, at moderate costs [13].
Membrane processes such as reverse osmosis (RO), nanofiltration (NF), and electrodialysis (ED) have drawn more attention because of their strong separation capabilities and exhibiting a great potential for the treatment of water worldwide. In the recent years, RO membrane technology is the leading technology for new desalination installations and has developed for both brackish and seawater applications. Brackish water RO membranes typically have higher product water flux, lower salt rejection, and require lower operating pressures due to lower osmotic pressure. But these membrane separation processes have some problems due to the formation of polarization films and by-products which may generate bacteria and fouling [8]. This problem may be overcome by using the alternative membrane technology such as membrane distillation for groundwater desalination.

\section{Groundwater Quality Scenario in India}

Groundwater is an essential and vital component of our life support system. It plays an imperative role in India's economic development. The rapid pace of agricultural development, industrialization and urbanization has resulted in the overexploitation and contamination of groundwater resources in parts of the country, resulting in various adverse environmental impacts and threatening its long-term sustainability.

The groundwater available in the country, in general, is potable and suitable for various usage. However, localized occurrence of groundwater having various chemical constituents in excess of the limits prescribed for drinking water use has been observed in almost all the states. The commonly observed contaminants such as arsenic, fluoride, and iron are geogenic, whereas contaminants such as nitrates, phosphates, and heavy metals owe their origin to various human activities including domestic sewerage, agricultural pesticides, and industrial effluents. Groundwater in shallow aquifers is generally suitable for use for different purposes such as drinking, agricultural, or industrial, which is mainly of calcium bicarbonate type and mixed cations and mixed anion type. However, other types of water are also available including sodium-chloride water $[9,14,15]$. The average limit of the toxic contamination available in the groundwater in different states of India is shown in Table 1. It shows that the values are higher than the permissible limit as per Indian standards and World Health Organization (WHO) guidelines for drinking water [16].

\section{General Concept in Membrane Process}

In general, membrane treatment processes use either pressure-driven or electrical-driven technologies. Pressuredriven membrane operation can be divided into four overlapping categories: reverse osmosis (RO), nanofiltration (NF), ultrafiltration (UF), and microfiltration (MF). The characteristics of applications of pressure-driven membrane processes are shown in Table 2. Reverse osmosis, and to some extent nanofiltration process, are considered effective in salt removal $[17,18]$. 
TABLE 1: Average limit of groundwater toxic contaminants available in different states of India [9].

\begin{tabular}{|c|c|c|c|c|c|}
\hline \multirow{2}{*}{$\begin{array}{l}\text { Sr. } \\
\text { No. }\end{array}$} & \multirow{2}{*}{ Indian state } & \multicolumn{4}{|c|}{ Characteristic limit in groundwater $(\mathrm{mg} / \mathrm{L})$} \\
\hline & & Fluoride & Iron & Arsenic & Nitrate \\
\hline 1 & Andhra Pradesh & $1.5-3.8$ & $1.1-8.43$ & NA & $46-1110$ \\
\hline 2 & Assam & $1.52-6.72$ & $1-10.13$ & $0.052-0.147$ & NA \\
\hline 3 & Bihar & $1.7-2.62$ & $1.12-10$ & $0.05-1.8$ & $48-228$ \\
\hline 4 & Chhattisgarh & $1.5-2.2$ & $1.0-7.5$ & 1.89 & $46-240$ \\
\hline 5 & Delhi & $1.58-4.42$ & NA & NA & $47-218$ \\
\hline 6 & Gujarat & $1.5-6.8$ & $1.1-3.24$ & NA & $45-520$ \\
\hline 7 & Haryana & $1.5-8.84$ & $1.1-17.78$ & NA & $49-1200$ \\
\hline 8 & Jammu and Kashmir & $2.0-2.06$ & $1.3-6.32$ & NA & $45-150$ \\
\hline 9 & Jharkhand & $1.6-2.5$ & $1.15-6.8$ & NA & $46-230$ \\
\hline 10 & Karnataka & $1.5-4.4$ & $1.0-16.2$ & NA & $46-247$ \\
\hline 11 & Kerala & $2.5-5.7$ & $1.0-9.0$ & NA & NA \\
\hline 12 & Madhya Pradesh & $1.5-10.7$ & $1.0-6.0$ & NA & $46-279$ \\
\hline 13 & Maharashtra & $1.5-4.01$ & $1.06-10.1$ & NA & $45-488$ \\
\hline 14 & Orissa & $1.52-4.9$ & $1.1-13.98$ & NA & $46-272$ \\
\hline 15 & Punjab & $1.54-8.33$ & $1.0-25.0$ & NA & $45-944$ \\
\hline 16 & Rajasthan & $1.5-35.15$ & $1.0-16.5$ & NA & $45-1005$ \\
\hline 17 & Tamil Nadu & $1.51-3.8$ & $1.49-2.93$ & NA & $45-654$ \\
\hline 18 & Uttar Pradesh & $1.5-2.96$ & $1.03-6.24$ & $0.05-0.195$ & $46-848$ \\
\hline 19 & West Bengal & $1.5-9.1$ & $1.0-17.3$ & $0.05-3.0$ & $46-81$ \\
\hline 20 & Andaman Nicobar & NA & NA & NA & NA \\
\hline 21 & Goa & NA & $1.0-2.0$ & NA & NA \\
\hline 22 & Manipur & NA & $1.8-16.52$ & NA & NA \\
\hline 23 & Meghalaya & NA & $1.29-7.2$ & $\mathrm{NA}$ & NA \\
\hline 24 & Tripura & NA & $1.02-5.23$ & NA & NA \\
\hline 25 & Himachal Pradesh & NA & NA & NA & $45-65$ \\
\hline 26 & Uttarakhand & NA & NA & NA & $46-81$ \\
\hline
\end{tabular}

TABLE 2: Characteristics of applications of pressure-driven membrane processes [17].

\begin{tabular}{lccl}
\hline Membrane process & $\begin{array}{c}\text { Applied pressure } \\
(\mathrm{kPa})\end{array}$ & $\begin{array}{c}\text { Minimum particle } \\
\text { size removed }\end{array}$ & Pollutant removal (type, average removal efficiency\%) \\
\hline $\begin{array}{l}\text { Microfiltration } \\
\text { Ultrafiltration }\end{array}$ & $30-500$ & $0.1-3 \mu \mathrm{m}$ & $\begin{array}{l}\text { Turbidity }(>99 \%) ; \text { bacteria }(>99.99 \%) \\
\text { Turbidity }(>99 \%) ; \text { bacteria }(>99.99 \%) ; \text { TOC }(20 \%)\end{array}$ \\
Nanofiltration & $30-500$ & $0.01-0.1 \mu \mathrm{m}$ & $\begin{array}{l}\text { Turbidity }(>99 \%) \text { color }(.98 \%) ; \text { TOC }(>95 \%) ; \text { hardness } \\
(>90 \%) ; \text { sulfate }(>97 \%) ; \text { virus }(>95 \%)\end{array}$ \\
Reverse osmosis & $500-1000$ & $200-400$ daltons & $\begin{array}{l}\text { Salinity }(>99 \%) ; \text { color and DOC }(>97 \%) ; \text { nitrate }(85-95 \%) ; \\
\text { pesticide }(0-100 \%) ; \text { As, Cd, Cr, Pb, F removal }(40-98 \%)\end{array}$ \\
\hline
\end{tabular}

Wastewater treatment using membranes is experiencing stable growth, with projections exceeding a $15 \%$ annual growth up to the year 2010. Practically, all membrane categories can be found in wastewater treatment and water reuse; however, MF and $\mathrm{RO}$ are the most representatives in this area [19]. Among various desalination technologies, membrane distillation (MD) is supposed to have a great potential due to low energy requirement, low operational pressure and temperature, and low-cost alternative to conventional technologies such as reverse osmosis (RO) and distillation [20-24]. MD process can be used for efficient purification of drinking water, which can remove all sorts of nonvolatiles.
Currently, there is no commercial product available in the market, which is based on the MD process.

3.1. RO Process: Basic Principle. $\mathrm{RO}$ is a physical process that uses the osmosis phenomenon, that is, the osmotic pressure difference between the salt water and the pure water to remove the salts from water [17]. $\mathrm{RO}$ is a pressuredriven membrane process where a feed stream flows under pressure through a semipermeable membrane, separating two aqueous streams, one rich in salt and other poor in salt. Water will pass through the membrane, when the applied pressure is higher than the osmotic pressure, while salt is 


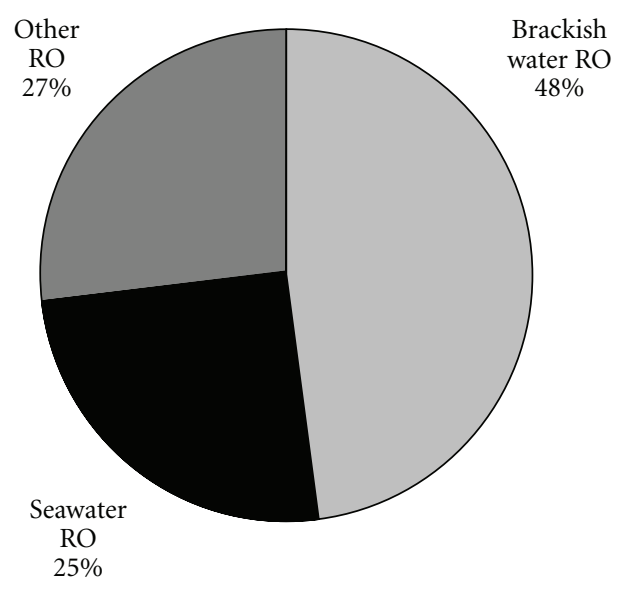

Figure 1: Percentage of RO desalination plant based on feed source of water in the world [3] (other RO plant feed source: river, wastewater, and pure water).

retained. As a result, a low salt concentration permeate stream is obtained and a concentrated brine remains at the feed side [25].

A typical RO system consists of four major subsystems: pretreatment system, high-pressure pump, membrane module, and posttreatment system. Using a high-pressure pump, the pretreated feed water is forced to flow across the membrane surface. RO operating pressure ranges from 17 to 27 bars for brackish water and from 55 to 82 bars for seawater [26]. Brackish groundwater has a much lower osmotic pressure than seawater; therefore, its desalination requires much less energy. Also, lower pressures found in brackish-water RO system permit the use of low-cost plastic components [4].

RO membranes do not have distinct pores that traverse the membrane and lie at one extreme of commercial available membranes. The polymer material of membranes forms a layered, web-like structure, and water must follow a tortuous pathway through the membrane to reach the permeate side. The membrane manufacturers offer high salt rejection membranes for RO plants, and the membranes do not retain the initial salt rejection throughout the membrane's lifetime (up to 7 years with effective pretreatment). Temperature, salinity, target recovery, and cleaning methods can affect salt passage through normal membrane [3].

Brackish water RO plants tend to be smaller in production capacity than seawater RO plants, but a greater number of brackish water RO plants (48\% of the total number of plants) are in operation worldwide than seawater RO plants $(25 \%)$ as shown in Figure 1. The remaining desalination plants $(27 \%)$ consist of other feed waters, including rivers, wastewater, and pure water [3].

The main drawbacks of RO technology are the limited recovery and the environmental impact of rejected brines. Recovery and brine concentration are limited because increasing the brine concentration in $\mathrm{RO}$ would increase osmotic pressure and thus the energy consumption as well as scaling on the membrane surface [27]. Recovery of the seawater RO plant is 35 to $45 \%$, and brackish water RO plant is
75 to $90 \%$ reported in the literature [3]. Hence the feed water concentration and characteristics play an important role in the RO system design. Recent innovations in brackish water RO plant design have stemmed from a combined need for inland desalination and reduced concentrate production or increased product water recovery. Increasing RO plant design size and environmental awareness have also influenced interest in alternative concentrate management [28]. The key limiting factor to widespread use of inland desalination is the exorbitant cost of concentrate disposal. The ideal solution would be to further increase brackish water RO recovery, but membrane scaling limits RO systems. High recoveries (9599\%) typically seen in fresh water treatment plants cannot be achieved by RO plants commercially available today.

For seawater RO plants, the disposal method is usually discharge back into the same body of water, meaning that it is diluted into the large seawater body without influencing the feed water composition [29]. In the brackish water RO plants, if the concentrate discharged to surface water, can change the salinity of the receiving water. The change in salinity can change the concentration of dissolved oxygen (DO) in the water and negatively affect aquatic life; the slandered limit for surface water discharge is a salinity difference of less than $10 \%$ [28]. Also, the rejected brines contain the high concentration of toxic contaminants which have serious effect on the human life and agriculture. Hence, it needs to reduce the volume of the concentrate stream, ultimately to increase the recovery of the RO plant. It also affects the cost of product.

3.2. MD Process: Basic Principle. MD is known since 1963 and is still being developed at laboratory stage for different purposes and not fully implemented in industry. MD is a thermal, vapor-driven transportation process through microporous and hydrophobic membranes. The term MD comes from the similarity of the MD process to conventional distillation as both technologies are based on the vapor/liquid equilibrium for separation, and both require heat to be supplied to the feed solution in order to achieve the necessary latent heat of vaporization. MD is applied as a nonisothermal membrane process in which the driving force is the partial pressure gradient across a membrane that is porous, not wetted by the process liquid. In this process, saline water is heated to increase its vapor pressure, which generates the difference between the partial pressure at both sides of the membrane. Hot water evaporates through nonwetted pores of hydrophobic membranes, which cannot be wetted by the aqueous solutions in contact with and only vapor and noncondensable gases should be present within the membrane pores. The passing vapor is then condensed on a cooler surface to produce fresh water [20,30-32].

The commercially available membranes are made mainly of polypropylene (PP), polytetrafluoroethylene (PTFE), polyvinylidene fluoride (PVDF), and polyethelene (PE). These are used in MD process and are available in tubular, capillary, or flat sheet forms. The choice of a membrane for a given $\mathrm{MD}$ application is a compromise between a low thermal conductivity achieved by thicker membranes, a high permeate flux achieved by thin membrane, a suitable pore 
TABLE 3: Recovery of water in RO and MD plant.

\begin{tabular}{lccc}
\hline \multirow{2}{*}{ Feed source } & \multicolumn{2}{c}{ Recovery \% } & \multirow{2}{*}{ Reference } \\
& RO plant & MD plant & \\
\hline Seawater & 40.08 & 77 & {$[18]$} \\
Groundwater & 90 & NA & {$[3]$} \\
\hline
\end{tabular}

size, as well as a high porosity and a high separation factor $[11,19,20,32]$.

In $\mathrm{MD}$, simultaneous heat and mass transfer phenomena through the membrane, different MD configurations may be employed to impose a vapor pressure difference across the membrane to drive a flux. The permeate side may be a cold liquid in direct contact with the membrane, called direct contact membrane distillation (DCMD), a condensing surface separated from the membrane by an air gap, called air gap membrane distillation (AGMD), a sweep gas blown across the membrane called sweep gas membrane distillation (SGMD), or vacuumed, called vacuum membrane distillation (VMD). Because AGMD and DCMD do not need an external condenser, they are best suited for applications where water is the permeating flux. SGMD and VMD are typically used to remove volatile organic or dissolved gas from an aqueous solution [11, 19, 20, 31, 33-35].

The potential applications of MD are production of high purity of water, concentration of ionic, colloid or other nonvolatile aqueous solutions, and removal of trace volatile organic compounds from wastewater. Various applications are involved in MD such as desalination of seawater or brackish water, environmental cleanup, waterreuse, food, and medical. All these characteristics of MD process received worldwide attention from both academia and industry in the last decade. Furthermore, the MD process offers some advantages: it (1) can be performed at lower operating pressure and lower temperatures than the boiling point of feed solution, (2) requires lower vapor space, (3) is unlimited to high osmotic pressure, (4) permits very high separation factor of nonvolatile solute, (5) has potential applications for concentrating aqueous solutions or producing high-purity water, and (6) can use any form of low-grade waste heat or be coupled with solar energy systems which makes it attractive for production of potable water from brackish water in arid regions. The recovery of MD process is higher than the RO process for seawater desalination; the literature results are shown in Table 3 . The groundwater recovery by the MD is still not found in the literature. These advantages make MD more attractive than other popular separation processes. Additionally, the possibility of using waste heat and renewable energy sources enable MD technique to cooperate in conjunction with other processes in an industrial scale $[19,36-40]$. Hence, $\mathrm{MD}$ is a promising, yet still emerging technology for water treatment.

\section{Membrane Fouling}

Membrane fouling is the accumulation of materials at the surface or in the pores of a membrane, which decreases the permeate flux of the membrane [41]. It is the serious problem faced by the membrane process. Fouling is the process resulting in loss of the performance of a membrane due to deposition of suspended or dissolved substance on its pore [42].

4.1. RO Membrane Fouling. Membrane processes are often chosen since these applications achieve high removals of constituents such as dissolved solids, organic carbon, inorganic ions, and regulated and unregulated organic compounds. However, membrane fouling is a major obstacle for most applications in the drinking industry (water treatment and desalination), especially when high concentrations of natural organic matter and inorganic constituents occur. The fouling can be classified as inorganic, organic, and biofouling [43]. Therefore, membrane fouling is caused by dissolved inorganic $\left(\mathrm{BaSO}_{4}, \mathrm{CaSO}_{4}\right.$, and $\left.\mathrm{CaCO}_{3}\right)$ or organic components (humic acid), collides (suspended particles), bacteria, or suspended solids $[44,45]$. The fouling deposits mainly consisted of a mixture of organic matter, iron, phosphorous, and microorganism, in addition to the chemical constituents usually found in seawater or surface water [43]. Despite its potential in water treatment, certain limitations prohibit membrane process from large scale and continuous operation [46]. RO membrane achieves high removal of dissolved solids. NF membranes have low to moderate removal, and MF and UF membranes do not remove them at all $[47,48]$.

The critical fouling problem in brackish water RO system is salt precipitation and membrane scaling. The higher relative concentrations of calcium, carbonate, and sulfate, combined with the higher recoveries possible for brackish water, cause calcium sulfate and carbonate precipitates to be typical concerns in brackish water RO. An important factor in the membrane fouling potential of dissolved inorganic is concentration polarization. While calcium carbonate is often the primary precipitate of concern, many other salts can be problematic in brackish water RO. Calcium sulfate precipitation and membrane scaling in $\mathrm{RO}$ have been extensively studied [49-51].

Fouling increases resistance, which in turn reduces permeate flux. Resistances that are responsible for decreasing flux are membrane resistance $\left(R_{m}\right)$, concentration polarization resistance $\left(R_{\mathrm{cp}}\right)$, cake resistance $\left(R_{c}\right)$, and pore blocking resistance $\left(R_{p}\right)$. Therefore total resistance during membrane filtration can be expressed as

$$
R_{T}=R_{m}+R_{\mathrm{cp}}+R_{c}+R_{p} .
$$

The type of membrane such as porous and nonporous plays an important role in determining the resistance for flux decline caused by inorganic fouling; $\mathrm{R}_{p}$ is not applicable for nonporous membranes [46].

The main technique currently used to control fouling are the feed pretreatment and membrane cleaning. The primary goal of any RO pretreatment system (for seawater or brackish water) is to lower the fouling propensity of the water in the RO membrane system. Surface water resources (seawater and 
brackish water) typically have a greater propensity for membrane fouling and require more extensive pretreatment systems than groundwater resources. An excessively advanced pretreatment system significantly increases the installation cost. Conventional pretreatment typically consists of acid addition, coagulant/flocculent addition, disinfection, media filtration, and cartridge filtration. Although conventional pretreatment has been widely used for seawater and brackish water RO plants, variation feed water can cause variation in conventional pretreatment effectiveness. Often, colloids and suspended particles pass through conventional pretreatment and contribute to remove $\mathrm{RO}$ membrane fouling [3].

Jawar and Hoek [52] examined inorganic fouling by gypsum scale formation for brackish water. At 15 and $25^{\circ} \mathrm{C}$ gypsum scale formation resulted in slow, steady flux decline at recoveries as low as $10-20 \%$. In contrast, at $35^{\circ} \mathrm{C}$, flux decline was due to increasing feed solution osmotic pressure up to a recovery of about $70 \%$. These results suggest that high-temperature operation and brackish water RO processes could enable higher recovery and lower consumption, but operating near the limiting recovery creates an increased risk of a catastrophic fouling event.

4.2. MD Membrane Fouling. Fouling and scaling are two important mechanisms that affect stability of the MD process and lead to reduce the overall efficiency. Fouling and scaling can cause pore clogging in MD membranes which lead to reduce the membrane area available for water vaporization and hence reduce the permeate flow rate. In addition, such a buildup of fouling and scaling surfaces reduces the flow channel area which causes a pressure drop and lower flow rates, leading to higher temperature polarization effects and reduction in flux. Moreover, fouling and scaling may cause membrane partially wetting or severe membrane damage [53]. Consequently, membrane fouling increases the costs by increasing (1) energy consumption, (2) system down time, (3) necessary membrane area, and (4) construction, labor, time, and material costs for washing and cleaning processes $[38,46,54-56]$. The membrane fouling due to inorganic salt is dependent on several factors, including but not limited to, membrane characteristics, module geometry, feed solution characteristics, and operating conditions [46].

Theoretically, MD performance is not sensitive to high concentration of feed; however, the presence of these sparingly soluble salts may lead to membrane fouling at moderate concentration. The scaling that occurred from seawater at moderate concentration appears to be readily removed from the membrane surface, and benefits from operating at low temperature may be marginal [54].

In high-concentration salt solution DCMD experiments, membrane fouling must be regarded highly [38]. The fouling in VMD is highly reversible and can be easily removed by a water washing. Indeed, permeability measurements before and after the experiments (after filtration and washing) show a variation less than 5\% [27]. A lower reversible fouling could occur for longer experiment [57].

The fouling is fewer problems in MD than in other membrane separation. The premise is that the pores are relatively large compared to the pores or diffusion pathways in RO or NF (both have pore sizes $<2 \mathrm{~nm}$, approximately two orders of magnitude smaller than those of MD membranes), which are not as easily clogged [58].

A sharp decline of the permeate flux during MD process of tap water was observed by Gryta [35]. The precipitation of $\mathrm{CaCO}_{3}$ on the membrane surface was the major reason of the observed flux decline during the purification of tap water by MD process. The deposit layer changed the temperature polarization and creates an additional thermal resistance, thus decreasing the heat transfer coefficient from the feed bulk to the evaporation and condensation surface, and temperature polarization increased. The adherence of the deposit to the membrane is a critical factor for MD performance, as well as other membrane processes. The deposit of $\mathrm{CaCO}_{3}$ on the membrane surface can easily be removed by rinsing the module with a $3 \mathrm{wt} \%$ solution of $\mathrm{HCl}$, what allowed to restore the initial permeate flux. After acid rinsing, the images of membrane surface were similar to that observed for a new membrane [35].

Drioli and $\mathrm{Wu}$ [59] have measured the variation of permeate flux with time over a 6 -day period for $0.58 \mathrm{wt} \% \mathrm{NaCl}$ solution using Gelman (TF450) $0.45 \mu \mathrm{m}$ pore membrane. Initially the flux was $5.83 \mathrm{~kg} / \mathrm{m}^{2} \mathrm{~h}$, and decreased during the first 3 days to a constant value of $1.66 \mathrm{~kg} / \mathrm{m}^{2} \mathrm{~h}$.

The problems resulting from biofouling were significantly lower than those encountered in other membrane processes. For example, in RO, a significantly larger number of bacteria, equal to $2.1 \times 10^{8}$ cells $/ \mathrm{cm}^{2}$, were found on the feed side of the membrane [60].

The groundwater obtained from RO plant (TDS of $19000 \mathrm{mg} / \mathrm{L}$ and TOC of $64 \mathrm{mg} / \mathrm{L}$ ) was performed in DCMD, found the results that the initial flux of $21 \mathrm{~L} / \mathrm{m}^{2} \mathrm{~h}$ was rapidly lost under high-temperature conditions until the membrane was totally covered with a recalcitrant foulant. Whereas a low temperature regime, with its initial lower flux of $16 \mathrm{~L} / \mathrm{m}^{2} \mathrm{~h}$, appeared to form larger amounts of loosely packed precipitate it was able to distil the RO secondary reject to greater than $67 \%$ recovery [54].

It is a general conclusion that pretreatment has an important positive influence on MD. But the fouling is not a major problem encountered in a MD process as compared to other pressure-driven membrane processes because MD performance is not sensitive to high concentration of feed; however, the presence of these sparingly soluble salts may lead to membrane fouling at moderate concentration.

\section{Energy Requirement and Recovery}

The well-established seawater and brackish groundwater desalination techniques, no doubt, can be employed to produce large amounts of good-quality water at a cost that as of today appears to be reasonably quite competitive, but the main drawback of all such processes still remaining to be resolved is the high energy consumption. The energy for the desalination plant is generally supplied in the form of either steam or electricity. The only electrical energy required is for pumping the water to a relatively high operating pressure $[4,13]$. 
5.1. RO Plant. In $\mathrm{RO}$ process for occurrence of reverse osmosis, a very high pressure is to be applied on the concentrated solution [61]. The primary energy use in RO system is the power required to pump the feed water and is directly related to the feed pressure and flow rate. The high salt concentrations found in seawater require elevated hydrostatic pressures (up to $7000 \mathrm{kPa}$ ); the higher the salt concentration, the greater the pressure and pumping power needed to produce a desired permeate flux [3]. Hence, to required high head pumpsets which are generally energized by electrical energy, the energy centre in the RO process is the high-pressure pumpsets and approximately $70 \%$ energy required for these pumpsets [61]. The required hydrostatic pressure must be greater than the osmotic pressure on the feed (concentrate) side of the membrane. As the recovery of a RO unit increases, the osmotic pressure increases on the feed side of the membrane, thus increasing the feed pressure required. However, as the recovery increases, the feed flow required decreases (for a specific product flux), and for lower recoveries (35-50\%), the overall energy requirement decreases with increasing recovery. Thus, a minimum energy requirement exists, typically at a recovery between 50 and $55 \%$, which varies with feed salinity [3].

In $\mathrm{RO}$ process, the rejected brine effluent will be having high pressure and having a considerable percentage of feed pressure. This available residual brine pressure can advantageously be utilized to boost the feed pressure of the raw water by suitable arrangement/device. This is called energy recovery system. Incorporating energy recovery equipment into $\mathrm{RO}$ system design is a logical and economical rewarding method for capturing the energy that otherwise would be discarded with high-pressure brine as a waste. Hydroturbines and impulse turbines are the two types of devices for recovering the residual energy available from the high-pressure feed stream. They have been used for many years in wide ranging applications, particularly in chemical industries [61]. Energy recovery devices can provide net energy transfer efficiency from the concentrate stream to the feed stream of more than $95 \%$ [3].

The coupling of energy sources with RO desalination plants has been an increased interest to development. But the renewable energy sources are still more expensive than traditional resources. Therefore, the unit cost operation for RO coupled with renewable energy is higher than for typical RO plants $[25,62,63]$. The main renewable energy sources available are solar, wind, and geothermal energy. The thermal energy sources are most often used with distillation desalination, while wind and photovoltaic solar energy are commonly paired with RO desalination. Overall, the energy sources most often used are solar energy (70\% of market) and $\mathrm{RO}$ which has the majority $(62 \%)$ of the renewable energy desalination market $[3,25]$. The development of small RO systems in rural areas has been limited due to high capital cost investment required, but the use of renewable energy could enable more communities to take advantage of RO technology.

Brackish water systems using solar photovoltaic energy have a range of production from 0.1 to $60 \mathrm{~m}^{3} /$ day [3]. The energy recovery devices installed in the RO process can lead
TABLE 4: Energy requirement in RO and MD plant [68].

\begin{tabular}{ll}
\hline Process & Observations \\
\hline RO & $4 \mathrm{kWh} / \mathrm{m}^{3}$ for 5 to $10 \mathrm{~L} / \mathrm{m}^{2} \mathrm{~h}$ at $20^{\circ} \mathrm{C}$ \\
\multirow{2}{*}{$\mathrm{MD}$} & $\mathrm{VMD} ; 1.5 \mathrm{kWh} / \mathrm{m}^{3}$ for $120 \mathrm{~L} / \mathrm{m}^{2} \mathrm{~h} ; 1.3 \mathrm{kWh} / \mathrm{m}^{3}$ for \\
& $85 \mathrm{~L} / \mathrm{m}^{2} \mathrm{~h}$ at $25^{\circ} \mathrm{C}$ \\
\hline
\end{tabular}

to 25 to $30 \%$ of energy saving [61]. Energy recovery devices play vital role in cost-effective production of fresh water by $\mathrm{RO}$ desalination.

5.2. MD Plant. In MD, desalination plant is operated in conjunction with a power plant or any other source of waste heat, the cost of energy for heating the feed water is negligible, hence thermally polluted water can be treated economically. Other sources of energy such as renewable solar or geothermal energy could be utilized to heat the feed water. As opposed to warm condenser water, use of renewable sources would involve higher capital investment. However, this investment may eventually be paid off by lower operating costs. Although VMD process requires two pumps for operation, one for the feed and one for permeate, lower pressures are required compared to the high pressures required for RO operation. Low-pressure pumps are less expensive in both capital and operating costs. If the VMD configuration is employed, a vacuum permeate pump would be utilized; however, the operating cost is low due to the low pressure gradient on the pump [61, 64-67].

The VMD performed better than the DCMD, and the cross flow module resulted to be the most effective design for obtaining high fluxes with moderate energy consumptions. The lower value of energy consumption/permeate flow rate ratios obtained were $3.55 \mathrm{~kW} \mathrm{~h} / \mathrm{kg}$ (longitudinal-flow membrane module) and $1.1 \mathrm{~kW} \mathrm{~h} / \mathrm{kg}$ (cross flow membrane module) for DCMD and VMD tests, respectively [67]. Table 4 shows the observations of energy requirement in $\mathrm{RO}$ and MD plant.

MD could be convenient to utilize cheap heat sources such as solar energy, geothermal energy, and waste heat. Therefore, in combination with such cheap energy, MD was a process of phase transition, and utilization of heat energy could decrease due to latent heat of vaporization. To design proper energy recovery facilities would be of great practical values in energy saving [1].

\section{Conclusions}

The groundwater treatment is essential for the drinking purpose, which was found by the scenario of Indian groundwater quality. Desalination technologies create new sources of fresh water from seawater or brackish water. This paper summarizes the review on the fundamental aspects of RO and MD process for desalination. The field of $\mathrm{RO}$ membrane desalination has rapidly grown over the past 40 years to become the primary choice for new plant installation. Due to the high-pressure requirement, lower recovery, membrane fouling, and higher energy consumption, an alternative economical process for the production of safe drinking water 
is required. MD is known since 1963 and is still being developed at laboratory stage for different purposes and not fully implemented in industry. It has some significant advantages over RO process, including lower operating temperature and pressure, and thus possible to use energy sources such as renewable solar heat or waste heat, product quality, and higher resistance to fouling.

The major conclusions that could be drawn from the study are as follows:

(i) there is great opportunity for MD groundwater or brackish water desalination;

(ii) the technological process provides easy access of drinking water for the people in rural and remote areas;

(iii) it reduces dependency on conventional and depleting energy sources.

\section{References}

[1] Y. Li and K. Tian, "Application of vacuum membrane distillation in water treatment," Journal of Sustainable Development, vol. 2, no. 3, pp. 183-186, 2009.

[2] B. L. Pangarkar, P. V. Thorat, S. B. Parjane, and R. M. Abhang, "Performance evaluation of vacuum membrane distillation for desalination by using a flat sheet membrane," Desalination and Water Treatment, vol. 21, no. 1-3, pp. 328-334, 2010.

[3] L. F. Greenlee, D. F. Lawler, B. D. Freeman, B. Marrot, and P. Moulin, "Reverse osmosis desalination: water sources, technology, and today's challenges," Water Research, vol. 43, no. 9, pp. 2317-2348, 2009.

[4] T. Abraham and A. Luthra, "Socio-economic and technical assessment of photovoltaic powered membrane desalination processes for India," Desalination, vol. 268, no. 1-3, pp. 238248, 2011.

[5] R. Kumar, R. D. Singh, and K. D. Sharma, "Water resources of India," Current Science, vol. 89, no. 5, pp. 794-811, 2005.

[6] Ministry of Water Resources, "Integrated water resources development a plan for action," Report for the National Commission for Integrated Water Resource Development, 1999.

[7] G. Emerson, Every Drop is Precious: Greywater as an Alternative Water Source, vol. 98 of Research Bulletin no.4, Queensland Parliamentary Library, 1998.

[8] A. M'nif, S. Bouguecha, B. Hamrouni, and M. Dhahbi, "Coupling of membrane processes for brackish water desalination," Desalination, vol. 203, no. 1-3, pp. 331-336, 2007.

[9] B. M. Jha, "Ground water quality in shallow aquifers of India," Central ground water board, Ministry of water resources, Govt. of India, 2010.

[10] O. T. Komesli, K. Teschner, W. Hegemann, and C. F. Gokcay, "Vacuum membrane applications in domestic wastewater reuse," Desalination, vol. 215, no. 1-3, pp. 22-28, 2007.

[11] G. W. Meindersma, C. M. Guijt, and A. B. de Haan, "Desalination and water recycling by air gap membrane distillation," Desalination, vol. 187, no. 1-3, pp. 291-301, 2006.

[12] J. Xu, M. Furuswa, and A. Ito, "Air-sweep vacuum membrane distillation using fine silicone, rubber, hollow-fiber membranes," Desalination, vol. 191, no. 1-3, pp. 223-231, 2006.

[13] S. Otles and S. Otles, "Desalination techniques," Electronic Journal of Environmental, Agricultural and Food Chemistry, vol. 4, no. 4, pp. 963-969, 2004.
[14] M. D. Kumar and T. Shah, "Groundwater pollution and contamination in India: the emerging challenge," Research report, International water management Institute, South Asia regional programme, India project office.

[15] Ministry of Water Resource, Govt. of India, http://wrmin.nic .in/index3.asp? subsublinkid=782\&langid $=1 \&$ sslid $=801$.

[16] Report of Ministry of Water Resource, Govt. of India, http://wrmin.nic.in/writereaddata/linkimages/wq1195519416 3.pdf.

[17] T. Younos and K. E. Tulou, "Overview of desalination techniques," Journal of Contemporary Water Research and Education, vol. 132, no. 3, p. 10, 2005.

[18] F. Macedonio and E. Drioli, "Pressure-driven membrane operations and membrane distillation technology integration for water purification," Desalination, vol. 223, no. 1-3, pp. 396-409, 2008.

[19] M. Safavi and T. Mohammadi, "High-salinity water desalination using VMD," Chemical Engineering Journal, vol. 149, no. 1-3, pp. 191-195, 2009.

[20] T. Mohammadi and M. Safavi, "Application of Taguchi method in optimization of desalination by vacuum membrane distillation," Desalination, vol. 249, no. 1, pp. 83-89, 2009.

[21] Z. Jin, D. L. Yang, S. H. Zhang, and X. G. Jian, "Hydrophobic modification of poly(phthalazinone ether sulfone ketone) hollow fiber membrane for vacuum membrane distillation," Journal of Membrane Science, vol. 310, no. 1-2, pp. 20-27, 2008.

[22] T. Mohammadi and M. Akbarabadi, "Separation of ethylene glycol solution by vacuum membrane distillation (VMD)," Desalination, vol. 181, no. 1-3, pp. 35-41, 2005.

[23] J. Li, Z. Xu, Z. Liu et al., "Micro porous polypropylene and polyethylene hollow fibre membranes: Part 3. experimental studies on membrane distillation for desalination," Desalination, vol. 155, no. 2, pp. 153-156, 2003.

[24] Y. Xu, B. Zhu, and Y. Xu, "Pilot test of vacuum membrane distillation for seawater desalination on a ship," Desalination, vol. 189, no. 1-3, pp. 165-169, 2006.

[25] E. Mathioulakis, V. Belessiotis, and E. Delyannis, "Desalination by using alternative energy: review and state-of-the-art," Desalination, vol. 203, no. 1-3, pp. 346-365, 2007.

[26] A. Al-Karaghouli, D. Renne, and L. Kazmerski, "Review technical and economic assessment of photovoltaic-driven desalination systems," Renewable Energy, vol. 35, no. 2, pp. 323-328, 2010.

[27] J. P. Mericq, S. Laborie, and C. Cabassud, "Vacuum membrane distillation for an integrated seawater desalination process," Desalination and Water Treatment, vol. 9, pp. 293-302, 2009.

[28] M. C. Mickly, "Review of concentrate management options, ground water report 363, technical papers, case studies and desalination technology resource," in The Future of Desalination in Texas, vol. 2, Texas Water Development Board, 2004.

[29] C. Mooij, "Hamma water desalination plant: planning and funding," Desalination, vol. 203, no. 1-3, pp. 107-118, 2007.

[30] M. Gryta, "Desalination of thermally softened water by membrane distillation process," Desalination, vol. 257, no. 13, pp. 30-35, 2010.

[31] N. Tang, Q. Jia, H. Zhang, J. Li, and S. Cao, "Preparation and morphological characterization of narrow pore size distributed polypropylene hydrophobic membranes for vacuum membrane distillation via thermally induced phase separation,” Desalination, vol. 256, no. 1-3, pp. 27-36, 2010.

[32] M. Khayet, "Membranes and theoretical modeling of membrane distillation: a review," Advances in Colloid and Interface Science, vol. 164, no. 1-2, pp. 56-88, 2011. 
[33] M. A. Izquierdo-Gil and G. Jonsson, "Factors affecting flux and ethanol separation performance in vacuum membrane distillation," Journal of Membrane Science, vol. 214, no. 1, pp. 113-130, 2003.

[34] D. E. Suk, T. Matsuura, H. B. Park, and Y. M. Lee, "Development of novel surface modified phase inversion membranes having hydrophobic surface-modifying macromolecule for vacuum membrane distillations," Desalination, vol. 261, no. 3, pp. 300-312, 2010.

[35] M. Gryta, "Application of membrane distillation process for tap water purification," Membrane Water Treatment, vol. 1, no. 1, pp. 1-12, 2010.

[36] S. R. Pinappu, "Composite membranes for membrane distillation desalination process," Final report, New Mexico State University, 2010.

[37] "A solar desalination system using the membrane distillation process," Technical Boucher 46, CADDET Renewable Energy, Harwell, UK, 1996.

[38] Y. Yun, R. Ma, W. Zhang, A. G. Fane, and J. Li, "Direct contact membrane distillation mechanism for high concentration $\mathrm{NaCl}$ solutions," Desalination, vol. 188 , no. $1-3$, pp. 251-262, 2006.

[39] M. Khayet, M. P. Godino, and J. I. Mengual, “Theoretical and experimental studies on desalination using the sweeping gas membrane distillation method," Desalination, vol. 157, no. 13, pp. 297-305, 2003.

[40] A. M. Islam, Membrane Distillation Process for Pure Water and Removal of Arsenic, M.S. thesis, 2004.

[41] T. F. Speth, R. S. Summers, and A. M. Gusses, "Nanofiltration foulants from a treated surface water," Environmental Science and Technology, vol. 32, no. 22, pp. 3612-3617, 1998.

[42] J. R. V. Flora, "Stochastic approach to modeling surface fouling of ultrafiltration membranes," Journal of Membrane Science, vol. 76, no. 1, pp. 85-88, 1993.

[43] A. S. Al-Amoudi, "Factors affecting natural organic matter (NOM) and scaling fouling in NF membranes: a review," Desalination, vol. 259, no. 1-3, pp. 1-10, 2010.

[44] B. van der Bruggen, C. Vandecasteele, T. van Gestel, W. Doyen, and R. Leysen, "A review of pressure-driven membrane processes in wastewater treatment and drinking water production," Environmental Progress, vol. 22, no. 1, pp. 46-56, 2003.

[45] H. S. Vrouwenvelder, J. A. M. van Paassen, H. C. Folmer, J. A. M. H. Hofman, M. M. Nederlof, and D. van der Kooij, "Biofouling of membranes for drinking water production," Desalination, vol. 118, no. 1-3, pp. 157-166, 1998.

[46] S. Shirazi, C. Lin, and D. Chen, "Inorganic fouling of pressuredriven membrane processes-a critical review," Desalination, vol. 250, no. 1, pp. 236-248, 2010.

[47] A. M. Farooque, A. S. Al-Amoudi, and A. M. Hassan, "Chemical cleaning experiments for performance restoration of NF membranes operated on seawater feed," in Proceedings of the IDA Conference, Manama, Bahrain, March 2002.

[48] A. S. Al-Amoudi and A. M. Farooque, "Performance restoration and autopsy of NF membranes used in seawater pretreatment," Desalination, vol. 178, no. 1-3, pp. 261-271, 2005.

[49] D. Hasson, A. Drak, and R. Semiat, "Inception of CaSO4 scaling on RO membranes at various water recovery levels," Desalination, vol. 139, no. 1-3, pp. 73-81, 2001.

[50] R. W. Lee, J. Glater, Y. Cohen et al., "Low-pressure RO membrane desalination of agricultural drainage water," Desalination, vol. 155, no. 2, pp. 109-120, 2003.

[51] A. Rahardianto, W. Y. Shih, R. W. Lee, and Y. Cohen, "Diagnostic characterization of gypsum scale formation and control in RO membrane desalination of brackish water,"
Journal of Membrane Science, vol. 279, no. 1-2, pp. 655-668, 2006.

[52] A. Jawor and E. M. V. Hoek, "Effects of feed water temperature on inorganic fouling of brackish water RO membranes," Desalination, vol. 235, no. 1-3, pp. 44-57, 2009.

[53] A. Kullab and A. Martin, "Membrane distillation and applications for water purification in thermal cogeneration plants," Separation and Purification Technology, vol. 76, no. 3, pp. 231237, 2011.

[54] N. Dow, J. Zhang, M. Duke, J. Li, S. R. Gray, and E. Ostarcevic, "Membrane distillation of brine wastes," Research Report 63, Water Quality Research Australia Ltd, 2008.

[55] M. Gryta, "Effect of iron oxides scaling on the MD process performance," Desalination, vol. 216, no. 1-3, pp. 88-102, 2007.

[56] S. Srisurichan, R. Jiraratananon, and A. G. Fane, "Mass transfer mechanisms and transport resistances in direct contact membrane distillation process," Journal of Membrane Science, vol. 277, no. 1-2, pp. 186-194, 2006.

[57] C. Tansakul, S. Laborie, and C. Cabassud, "Membrane hybrid processes for pretreatment before seawater reverse osmosis desalination," Desalination and Water Treatment, vol. 9, no. 13, pp. 279-286, 2009.

[58] A. M. Alklaibi and N. Lior, "Membrane-distillation desalination: status and potential," Desalination, vol. 171, no. 2, pp. 111-131, 2005.

[59] E. Drioli and Y. Wu, "Membrane distillation : an experimental study," Desalination, vol. 53, no. 1-3, pp. 339-346, 1985.

[60] H. S. Vrouwenvelder, J. A. M. van Paassen, H. C. Folmer, J. A. M. H. Hofman, M. M. Nederlof, and D. van der Kooij, "Biofouling of membranes for drinking water production," Desalination, vol. 118, no. 1-3, pp. 157-166, 1998.

[61] L. Muthumariappan, "Energy conservation systems in reverse osmosis desalination plants," TWAD Technical Newsletter, January, 2004.

[62] A. M. Helal, S. A. Al-Malek, and E. S. Al-Katheeri, "Economic feasibility of alternative designs of a PV-RO desalination unit for remote areas in the United Arab Emirates," Desalination, vol. 221, no. 1-3, pp. 1-16, 2008.

[63] A. Lamei, P. V. Zaag, and E. V. Münch, "Impact of solar energy cost on water production cost of seawater desalination plants in Egypt," Energy Policy, vol. 36, no. 5, pp. 1748-1756, 2008.

[64] T. Y. Cath, V. D. Adams, and A. E. Childress, "Experimental study of desalination using direct contact membrane distillation: a new approach to flux enhancement," Journal of Membrane Science, vol. 228, no. 1, pp. 5-16, 2004.

[65] A. Criscuoli, M. C. Carnevale, and E. Drioli, "Energy requirements in membrane distillation: evaluation and optimization," Desalination, vol. 200, no. 1-3, pp. 586-587, 2006.

[66] F. Macedonio, E. Curcio, and E. Drioli, "Integrated membrane systems for seawater desalination: energetic and exergetic analysis, economic evaluation, experimental study," Desalination, vol. 203, no. 1-3, pp. 260-276, 2007.

[67] A. Criscuoli, M. C. Carnevale, and E. Drioli, "Evaluation of energy requirements in membrane distillation," Chemical Engineering and Processing, vol. 47, no. 7, pp. 1098-1105, 2008.

[68] M. Busch, R. Chu, U. Kolbe, Q. Meng, and S. Li, "Ultrafiltration pretreatment to reverse osmosis for seawater desalination-three years field experience in the Wangtan Datang power plant," Desalination and Water Treatment, vol. 10, no. 1-3, pp. 1-20, 2009. 

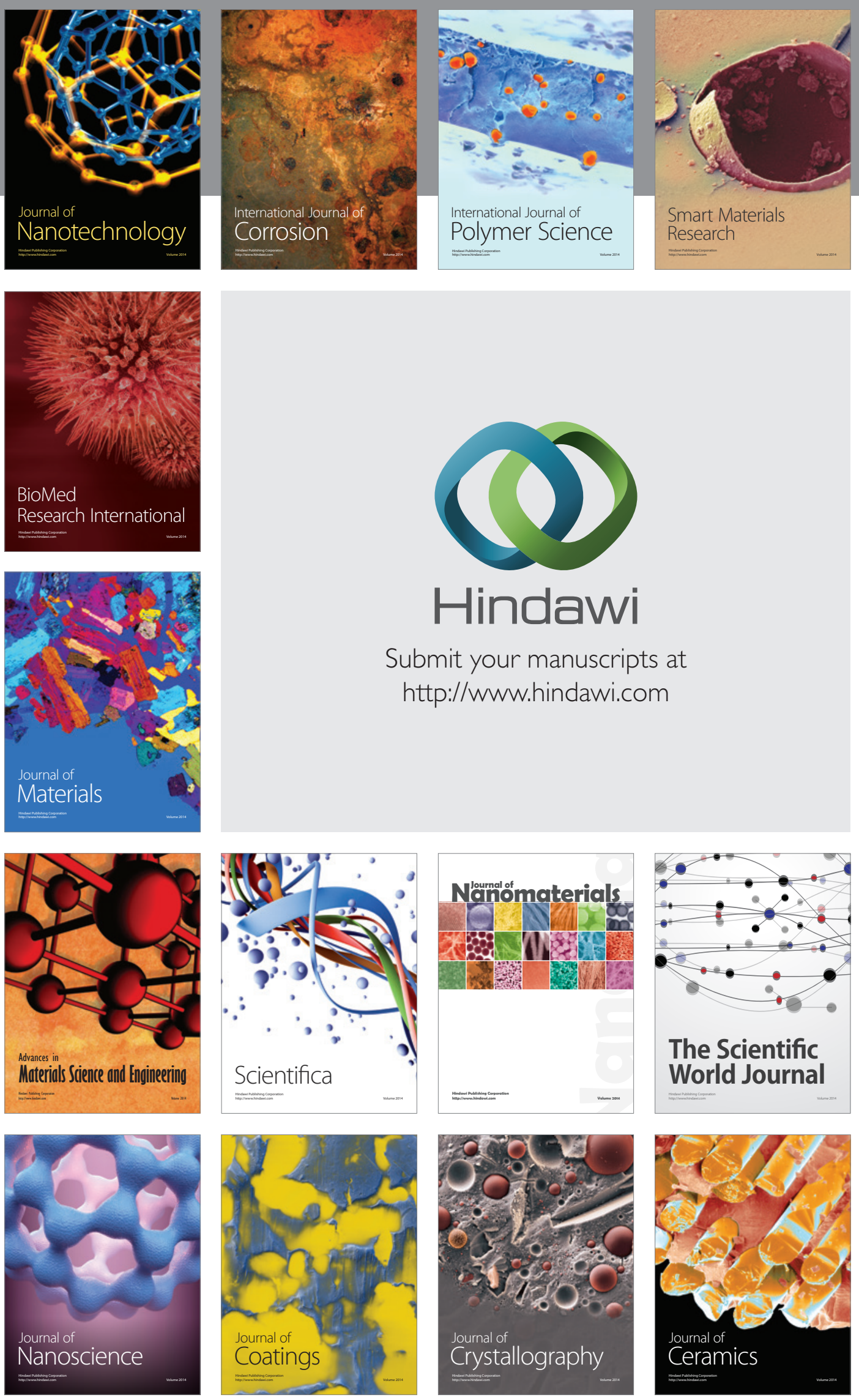

The Scientific World Journal

Submit your manuscripts at

http://www.hindawi.com

\section{World Journal}

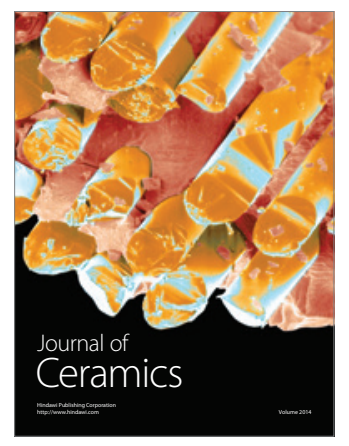

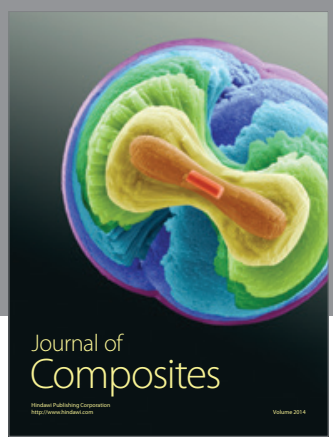
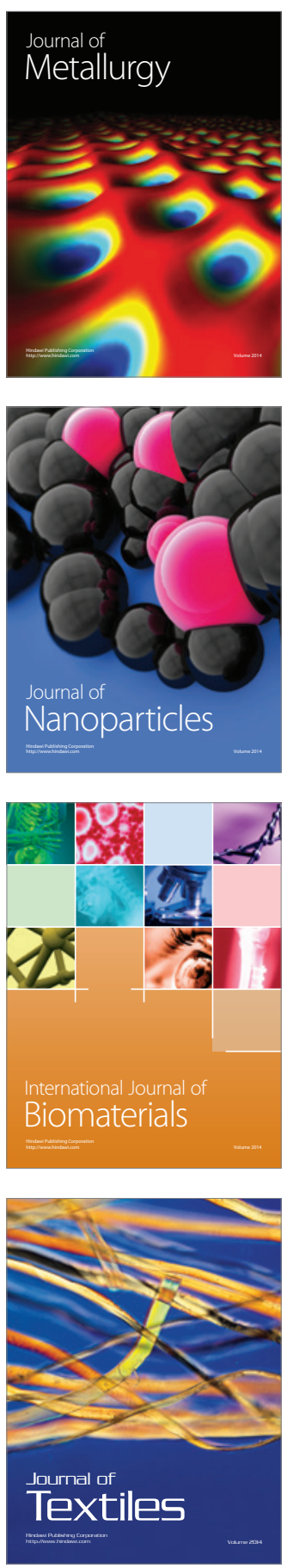